\title{
Comparative analysis of the management of acute appendicitis between the normal period and COVID-19 pandemic
}

\author{
Serhat Meriç, M.D., (ㄱ) Talar Vartanoğlu Aktokmakyan, M.D., (1) Merve Tokocin, M.D.,

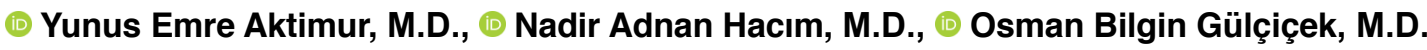

Department of General Surgery, İstanbul Bağcılar Training and Research Hospital, İstanbul-Turkey

\begin{abstract}
BACKGROUND: Acute appendicitis is the most common abdominal surgical emergency. There is no adequate information to evaluate the effects of the COVID-I9 pandemic on acute appendicitis and its surgical management. The present comparative study reports successful appendectomy and infection control in patients with appendicitis during the COVID-19 pandemic and last year covering the same period.
\end{abstract}

METHODS: This retrospective observational study was conducted in acute appendicitis-treated patients from 13.03.19 to 13.05.19 and from 13.03.20 to 13.05.20, respectively.

RESULTS: This study included I50 patients (II0 patients in 2019; 40 patients in 2020 (during COVID-19 pandemic)). The patients were named as Group A (Normal period) and Group B (Pandemic period), respectively. The groups were comparable as there was no significant difference between the mean age, mean BMI, and mean length of stay. There is a significant difference between the comorbidities of Group A and Group B $(p=0.033)$. There was no significant difference between the laboratory and radiological findings of Group A and Group B. There was a significant difference between the perforation number of Group A and Group B ( $p=0.029$ ). There was no significant difference between the needs of ICU and conversion from laparoscopic to conventional appendectomy of Group A and Group B.

CONCLUSION: The findings obtained in this study suggest that late admission to the hospital caused complicated cases and made acute appendicitis management more difficult during the pandemic period, which was already a troubling period. During the COVID-19 pandemic, the principles applied to emergency surgery for infected patients should be applied to both suspected and confirmed cases. Keywords: Appendectomy; Coronavirus disease 2019 (COVID-19); severe acute respiratory syndrome coronavirus 2 (SARS-CoV-2).

\section{INTRODUCTION}

Pneumonia caused by SARS-CoV-2 infection emerged in Wuhan City, China, in December 2019. The World Health Organization (WHO) officially named the disease resulting from infection with SARS-CoV-2 as coronavirus disease 2019 (COVID- 19). ${ }^{[1]}$ According to the World Health Organization (WHO), as of 10 AM CEST 6 May 2020, 10,533,779 people were infected while 512,842 people have died so far. ${ }^{[2]}$ COVID- 19 outcomes a wide spectrum of clinical manifesta- tions that typically include fever, dry cough, myalgia, and fatigue, often with pulmonary involvement. Acute appendicitis is the most common abdominal surgical emergency. Similarly, acute appendicitis is the most common abdominal surgical emergency in the COVID-19 pandemic period. There is no adequate information to evaluate the effects of the COVID-19 pandemic on acute appendicitis and its surgical management. The present comparative study reports successful appendectomy and infection control in patients with appendicitis during the COVID- 19 pandemic and last year covering the same period.

Cite this article as: Meriç S, Vartanoğlu Aktokmakyan T, Tokocin M, Aktimur YE, Hacım NA, Gülçiçek OB. Comparative analysis of the management of acute appendicitis between the normal period and COVID-19 pandemic. Ulus Travma Acil Cerrahi Derg 2021;27:22-25.

Address for correspondence: Talar Vartanoğlu Aktokmakyan, M.D.

İstanbul Bağcılar Eğitim ve Araştırma Hastanesi, Genel Cerrahi Kliniği, İstanbul, Turkey

Tel: +90 212 - 4404000 E-mail: talarim@gmail.com

Ulus Travma Acil Cerrahi Derg 202I;27(I):22-25 DOI: 10.14744/tjtes.2020.46487 Submitted: 25.08.2020 Accepted: 13.1I.2020 Online: 08.12.2020

Copyright 2021 Turkish Association of Trauma and Emergency Surgery 


\section{MATERIALS AND METHODS}

A retrospective observational study was conducted on patients operated on for Acute Appendicitis from 13.03.19 to 13.05.19 and from 13.03.20 to 13.05.20 comparatively, in Istanbul Bagcilar Training and Research Hospital as a pandemic hospital, after ethical approval was taken from both local ethics committee (2020.07.2.09. I I0) and the Ministry of Health. That is, appendectomies corresponding to the pandemic process were compared with appendectomies performed in the same period last year. They were classified according to the year of the appendectomy as Group A and Group $B$. The surgical intervention administered was not different from the usual technique and was the same for both groups. An evaluation was made of characteristics of the patients, comorbidities, laboratory findings, radiological findings, hospital stay, and complications. The data were collected using Microsoft Excel ${ }^{\circledR}$, and the variables were analyzed using the IBM SPSS Statistics ${ }^{\circledR} 25.0$ statistical packages. Chi-square test and Mann-Whitney $U$ test were used for statistical analysis. "p-value" less than 0.05 was considered statistically significant $(p<0.05)$.

\section{RESULTS}

This study included 150 patients (II0 patients in 2019; 40 patients in 2020 (during COVID-19 pandemic) with a mean age of 29.1 and 34, respectively (Table I). The patients were named as Group A (Normal period) and Group B (Pandemic period), respectively, according to the year they were operated on. The groups were comparable as there was no significant difference between the mean age, mean $\mathrm{BMI}$, and mean length of stay.

According to the comorbidities, patients were categorized (Tables 2 and 3). There was a significant difference between the comorbidities of Group A and Group B ( $p=0.033)$. The patients are compared concerning comorbidities in Table 2 and Table 3 by the side of the total number of patients.

According to the laboratory and radiological findings, patients were categorized (Tables 4 and 5). There was no significant difference between the laboratory and radiological findings of Group A and Group B.

Table I. Characteristics of 2019 and 2020 appendectomies

\begin{tabular}{lccc}
\hline Appendectomies & $\begin{array}{c}\text { Group A } \\
(\mathbf{n}=\mathbf{I} \mathbf{1 0})\end{array}$ & $\begin{array}{c}\text { Group B } \\
(\mathbf{n = 4 0 )}\end{array}$ & $\mathbf{p}$ \\
\hline Female/Male & $37 / 73$ & $12 / 28$ & 0.532 \\
Mean Age & 29.1 & 34 & 0.103 \\
Mean BMI & $26.2 \mathrm{~kg} / \mathrm{m}^{2}$ & $26.5 \mathrm{~kg} / \mathrm{m}^{2}$ & 0.453 \\
Mean length of stay & 1.7 day $[\mathrm{I}-\mathrm{I}]$ & 1.48 day $[\mathrm{I}-6]$ & 0.188 \\
\hline
\end{tabular}

BMI: Body Mass Index.
Table 2. Comorbidities of 2019 appendectomies

\begin{tabular}{ll}
\hline Comorbidities & Number of patients \\
\hline Diabetes mellitus & $\mathrm{I}$ \\
Diabetes mellitus+Hypertension & $\mathrm{I}$ \\
Hypertension+Chronic kidney disease & $\mathrm{I}$ \\
Hypertension & 2 \\
Chronic bronchitis and asthma & $\mathrm{I}$ \\
Epilepsy & $\mathrm{I}$ \\
\hline
\end{tabular}

Table 3. Comorbidities of 2020 appendectomies

\begin{tabular}{ll}
\hline Comorbidities & Number of patients \\
\hline Diabetes mellitus & 3 \\
Hypertension & 1 \\
Chronic artery disease & 2 \\
Hypertension+Atrial fibrillation & 2 \\
\hline
\end{tabular}

Table 4. Laboratory findings of the included patients

\begin{tabular}{|c|c|c|c|}
\hline Laboratory findings & $\begin{array}{l}\text { Mean of } \\
\text { Group A }\end{array}$ & $\begin{array}{l}\text { Mean of } \\
\text { Group B }\end{array}$ & $\mathbf{p}$ \\
\hline WBC (10×3/uL) & 14.7 & 15.6 & 0.673 \\
\hline LYM (10×3/uL) & 2.24 & 2.22 & 0.968 \\
\hline NEU (10×3/uL) & 11.5 & 11.4 & 0.720 \\
\hline PLT (10×3/uL) & $27 \mid$ & 256.2 & 0.218 \\
\hline $\mathrm{CRP}(\mathrm{mg} / \mathrm{L})$ & 44.8 & 53.4 & 0.882 \\
\hline
\end{tabular}

WBC: White blood cell; LYM: Lymphocyte; NEU: Neutrophil: PLT: Platelet; CRP: C-reactive protein.

Table 5. Radiological findings of the included patients

\begin{tabular}{lccc}
\hline $\begin{array}{l}\text { Radiological } \\
\text { findings }\end{array}$ & Group A & Group B & p \\
\hline US & $85 \mathrm{~mm}[55-120]$ & $87 \mathrm{~mm}[60-130]$ & 0.520 \\
CT & $99 \mathrm{~mm}[4.8-20]$ & $99.5 \mathrm{~mm}[60-130]$ & 0.128 \\
\hline & &
\end{tabular}

Table 6. Complications of the included patients

\begin{tabular}{lccc}
\hline Complications & Group A & Group B & p \\
\hline Perforation & 7 & 7 & 0.029 \\
Intensive care unit need & 2 & 1 & 0.428 \\
Conversion from laparoscopic & 3 & 0 & 0.381 \\
to conventional appendectomy & & & \\
\hline
\end{tabular}


According to the complications, patients were categorized (Table 6). There was a significant difference between the perforation number of 2019 appendectomies and 2020 appendectomies $(p=0.029)$. There is no significant difference between the ICU need and conversion from laparoscopic to conventional appendectomy of 2019 appendectomies and 2020 appendectomies.

According to the RT-PCR (Reverse transcription-polymerase chain reaction) test and pre-operative radiological scanning of the lung, there was no COVID-I9 positive and/or suspicious patient in Group B.

\section{DISCUSSION}

The novel coronavirus disease 2019 (COVID-19) began in Wuhan, China, at the end of 2019 and spread rapidly across the country and worldwide. Then, it was declared to be a pandemic by the World Health Organization. ${ }^{[3]}$ COVID-19 is very arduous to control and manage the rising number of patients with relatively inadequate medical resources, and if all interest and resources are focused on the pandemic, a different emergency can be missed.

According to our study, during the current pandemic, at-risk patients should be treated in the same manner as patients with confirmed infection because we realized that the complication rates are the same despite the decrease in the number of patients admitted to the emergency department. That is why, because emergency cases cannot be treated in the same manner as they were before the COVID-19 outbreak, an approach proper to the type of emergency, the patient's condition, and the hospital's status is necessary. When the decrease in the number of patients is examined, we consider that the emergency administrations are decreasing, primarily because of the curfew of people, and most importantly, because they are afraid of pandemics. In this study, we reveal that the patients who apply wait until the last moment and apply when they cannot tolerate pain and suffering.

According to regulations made by the ministries of health, regular non-urgent surgeries have been delayed and these patients must go to a screening clinic before surgery to reduce the risk of hospital infection during the COVID-19 outbreak. Besides, all patients have to undergo a COVID-19 RT-PCR screening test and chest radiography. If the patients have symptoms of pneumonia, fever, or respiratory tract, traveled abroad in the past two weeks, or had a history of contact with patients with COVID-19, RT-PCR results are quarantined until results areobtained. However, this is, of course, unlikely for emergency surgeries. Although benign elective surgical procedures can be postponed to a distant time during this pandemic, surgical interventions for urgent and life-threatening situations are mandatory to perform. ${ }^{[4]}$

In recent studies, some surgical guidelines regarding COVID- 19 have suggested that an antibiotic trial for uncom- plicated or early appendicitis may be considered depending on the surgeon's judgment and the patient's condition. However, if it is thought that delaying the surgery will prolong hospital stay, increase the probability of hospitalization or harm the patient. ${ }^{[5,6]}$

To maintain the sustainability of the healthcare system, the protection of health-care providers should be the top priority, and hospitals should reorganize themselves, provide decent protective equipment to all staff and use the workforce effectively. ${ }^{[7]}$ In our hospital, where we conducted this study, which is a pandemic hospital, after the computerized tomography of the patients were taken, all emergency operations, including appendectomy, continued taking into consideration the safety of the personnel with the personal protective equipment in the operating rooms where the negatives were operated if COVID-Negative was operated, and in the operating rooms where COVID-Positive or suspect positive patients were operated. After the operation, isolation was tried to be divided by dividing the clinics where the patients will be followed, and this strategy can be developed if the physical conditions allow. The most important issue here is that the entire team that will contact the patient before, during, and after the surgery is trained and takes all necessary measures to reduce contamination. ${ }^{[8]}$

Medical treatment can be a possible and applicable alternative today to manage the many patients in whom the diagnosis of acute uncomplicated appendicitis is made and access to the operating room impossible. In some studies, researchers indicated that the initiation of the therapeutic alternative could be offered safely and knowingly by all visceral surgeons and in proportion to the needs of the care center concerned. ${ }^{[9]}$ A study that has been conducted suggest that the significant reduction in the number of patients admitted with AA during the onset of COVID-1 9 will likely to be successfully resolved mild appendicitis treated symptomatically by patients at home. ${ }^{[10]}$

As limitations of this study, we have its retrospective nature, which makes it impossible to randomize patients, and the small number of the sample analyzed in a short period.

\section{Conclusion}

COVID-19 pandemic influenced the time of diagnosis of appendicitis, as well as its course and management type. As seen in our study, late admission to the hospital caused complicated cases and made acute appendicitis management more difficult during the pandemic period, which was already a troubling period. During the COVID-19 pandemic, the principles applied to emergency surgery for infected patients should be applied to both suspected and confirmed cases. Also, emergency surgery should not be postponed due to the delay in obtaining COVID-19 test results. Emergency surgery instructions in COVID- 19 patients should be prepared in ad- 
vance according to the hospital environment and the special conditions of the patient.

Ethics Committee Approval: Approved by the local ethics committee (2020.07.2.09.110).

Peer-review: Internally peer-reviewed.

Authorship Contributions: Concept: S.M., N.A.H.; Design: M.T., S.M.; Supervision: O.B.G.; Resource: N.A.H.; Materials: Y.E.A., M.T.; Data: Y.E.A.; Analysis: T.V.A.; Literature search: T.V.A.; Writing: T.V.A.; Critical revision: O.B.G., S.M.

Conflict of Interest: None declared.

Financial Disclosure: The authors declared that this study has received no financial support.

\section{REFERENCES}

1. Cucinotta D, Vanelli M. WHO Declares COVID-19 a Pandemic. Acta Biomed 2020;91:157-60.

2. WHO. Coronavirus disease 2019 (COVID-19) Situation Report - 164. Available from: https://www.who.int/docs/default-source/ coronaviruse/situation-reports/20200702-covid-19-sitrep-164.pdf?sfvrsn=ac074f58_2.

3. Mahase E. Covid-19: WHO declares pandemic because of "alarming levels" of spread, severity, and inaction. BMJ 2020;368:1036. [CrossRef]
4. Çolakoğlu MK, Öter V, Bostancı EB, Özmen MM, Sarıbeyoğlu K. Surgical management of digestive system cancers during the coronavirus disease 2019 pandemic: review of general suggestions. Turk J Surg 2020;36:121-31. [CrossRef]

5. American College of Surgeons. COVID-19 Guidelines for Triage of Emergency General Surgery Patients. Available from: https://www.facs. org/covid-19/clinical-guidance/elective-case/emergency-surgery.

6. Royal College of Surgeons of England. Updated Intercollegiate General Surgery Guidance on COVID-19. Available from https://www.rcseng. ac.uk/coronavirus/joint-guidance-for-surgeons-v2.

7. Gok AFK, Eryılmaz M, Ozmen MM, Alimoglu O, Ertekin C, Kurtoglu MH. Recommendations for Trauma and Emergency General Surgery Practice During COVID-19 Pandemic. Ulus Travma Acil Cerrahi Derg 2020;26:335-42. [CrossRef]

8. Erol V, Sümer A, Savaş OA, Pekşen Ç, Gülay H, Aktimur R, et al. Recommendations for bariatric and metabolic surgical operations during the COVID-19 pandemic in Turkey. Turk J Surg 2020;36:132-6. [CrossRef]

9. Collard M, Lakkis Z, Loriau J, Mege D, Sabbagh C, Lefevre JH, et al. Antibiotics alone as an alternative to appendectomy for uncomplicated acute appendicitis in adults: Changes in treatment modalities related to the COVID-19 health crisis. [ Article in French]. J Chir Visc 2020;157:S33-43. [CrossRef]

10. Tankel J, Keinan A, Blich O, Koussa M, Helou B, Shay S, et al. The Decreasing Incidence of Acute Appendicitis During COVID-19: A Retrospective Multi-centre Study. World J Surg 2020;44:2458-63. [CrossRef]

\section{ORIJINAL ÇALIŞMA - ÖZET}

\section{Akut apandisit yönetiminin normal dönemde ve COVID-19 pandemisi esnasında karşılaştırmalı analizi \\ Dr. Serhat Meriç, Dr. Talar Vartanoğlu Aktokmakyan, Dr. Merve Tokocin, Dr. Yunus Emre Aktimur, Dr. Nadir Adnan Hacım, Dr. Osman Bilgin Gülçiçek}

İstanbul Bağcılar Eğitim ve Araştırma Hastanesi, Genel Cerrahi Kliniği, İstanbul

AMAÇ: Bilindiği üzere akut apandisit, en sık acil abdominal cerrahi nedenidir. COVID- 19 pandemisinin akut apandisit ve cerrahi tedavisi üzerindeki etkilerini değerlendirmek amacıyla yapılan çalışmalar kısıtlıdır ve yeterli bilgi mevcut değildir. Mevcut karşılaştırmalı çalışma, COVID- I9 pandemisi sırasında ve geçen yıl aynı periyodu kapsayan dönemde apendektomi ameliyatı geçiren hastaların apendektomi sonuçlarını ve enfeksiyon kontrolünü bildirmeyi amaçlamaktadır.

GEREÇ VE YÖNTEM: Gerçekleştirilen geriye dönük gözlemsel çalışma, karşılaştırmalı olarak 13.03.19-13.05.19 ve I3.03.20-13.05.20 tarihleri arasında akut apandisit nedeniyle ameliyat edilen hastalar üzerinde gerçekleştirildi.

BULGULAR: Çalışmaya 150 hasta (2019'da II0 hasta; 2020'de 40 hasta [COVID-19 pandemi sırasında]) dahil edildi ve hastalar sırasıyla Grup A (Normal dönem) ve Grup B (Pandemi dönemi) olarak isimlendirildi. Ortalama yaş, ortalama VKi ve ortalama kalış süresi arasında anlamlı bir fark olmadığı için istatistiksel olarak kıyaslanabilir gruplar olarak değerlendirildi. Grup A ve Grup B komorbiditeleri arasında anlamlı fark gözlendi $(p=0.033)$. Grup A ve Grup B'nin laboratuvar değerleri ve radyolojik bulguları arasında anlamlı bir fark yoktu. Grup A ile Grup B'nin perforasyon sayısı arasında anlamlı fark tespit edildi $(p=0.029)$. Grup A ve Grup B'nin yoğun bakım ihtiyacı ile laparoskopiden konvansiyonel apendektomiye geçiş sayıları arasında anlamlı bir fark yoktu.

TARTIŞMA: Çalışmamızda da görüldüğü üzere, hastaneye geç başvuru, komplike olgulara neden olmuş ve zaten sıkıntılı bir dönem olan pandemi sürecinde, akut apandisit yönetimini daha da zorlaştırmıştır. COVID-19 salgını sırasında, acil cerrahide uygulanan ilkeler hem şüpheli hem de doğrulanmış COVID-19 olgularına uygulanmalıdır.

Anahtar sözcükler: Akut solunum sendromu; apendektomi; Coronavirus hastalığı 2019 (COVID-19); Koronavirüs 2 (SARS-Cov-2).

Ulus Travma Acil Cerrahi Derg 2021;27(I):22-25 doi: 10.14744/tjtes.2020.46487 